\title{
EchoGéo
}

47| 2019

Nouvelles géographies de la collecte

\section{Waste, weeds, and wild food}

A critical geography of urban food collecting

\section{Flaminia Paddeu}

\section{(2) OpenEdition}

\section{Journals}

Electronic version

URL: https://journals.openedition.org/echogeo/16623

DOI: $10.4000 /$ echogeo. 16623

ISSN: 1963-1197

\section{Publisher}

Pôle de recherche pour l'organisation et la diffusion de l'information géographique (CNRS UMR 8586)

Electronic reference

Flaminia Paddeu, "Waste, weeds, and wild food", EchoGéo [Online], 47 | 2019, Online since 21 April 2019, connection on 10 August 2021. URL: http://journals.openedition.org/echogeo/16623; DOI: https://doi.org/10.4000/echogeo.16623

This text was automatically generated on 10 August 2021.

EchoGéo est mis à disposition selon les termes de la licence Creative Commons Attribution - Pas d'Utilisation Commerciale - Pas de Modification 4.0 International (CC BY-NC-ND) 


\title{
Waste, weeds, and wild food
}

\author{
A critical geography of urban food collecting \\ Flaminia Paddeu
}

\section{Introduction}

1 Although research is uneven in its scope, urban food collecting, whether through foraging or scavenging, is considered a global phenomenon. In cities of the Global North, it is practiced by the rich and the poor, the employed and the unemployed, migrants and long-term residents, whose motives and practices vary in time and place. As a set of informal ambulant practices to gather biological resources as well as food waste, urban food collecting is practiced in varied settings of urban, suburban and periurban landscapes, including common, state, and privately owned lands. Mostly bereft of monetary exchange, and relying on specific skills to locate, gather and sometimes process and distribute the resources, urban collecting practices are usually deterred by local governments.

Despite common features, foraging and scavenging for food do not entirely overlap regarding their practitioners, motives, spaces and representations. On the one hand, urban foraging is the practice of harvesting or gathering raw biological resources (fungi, plants, animals, and fish) within urban settings, primarily for direct food or medical consumption, decoration, crafts, ceremony, barter or small-scale sale (Shackleton et al., 2017). It can include wild or domesticated species, in managed or unmanaged spaces. Mostly practiced in rural and uninhabited settings (Short Gianotti and Hurley, 2016), foraging has recently gained momentum within cities such as Seattle, Baltimore, New York, Philadelphia or Syracuse (McLain et al., 2014; Plieninger et al., 2015; Synk et al., 2017), Stockholm, Berlin or Edinburgh (von Hoffen and Säumel, 2014), and in Finnish and Japanese towns (Terada et al., 2010; Kangas and Markkanen, 2001). On the other hand, urban scavenging is the practice of recuperating discarded goods in varied locations such as sidewalks, streets, or waste receptacles. In the Global North, the term "dumpster diving" has been broadly applied to various forms of food waste recovery and scavenging. In addition to dumpsters, participants often recuperate 
from public markets, "curb dive" (from waste awaiting removal from the roadside), "bin", "table dive" (from plate leftovers in restaurants), form informal agreements with retailers, and barter goods and services in local networks (Oakes, 2000; Vinegar, Parker, and McCourt, 2016). Urban scavenging is well documented in global cities including New York City and Los Angeles (Barnard, 2011, 2016b; Nguyen et al., 2014), Montreal (Vinegar et al., 2016), or Paris (Guien and Ramirez, 2017).

3 Several collecting options are available for those who, for many reasons, circumvent, supplement, or are unable to access the conventional food system. Yet little is known about patterns of urban food collecting and how this knowledge would affect a geography of collecting. The objective of this paper is twofold. Firstly, it provides a review of the literature on varied forms of food collecting in urban and suburban settings of Northern metropolises. By focusing on a "forager-scavenger continuum" instead of opposing foraging for wild food to scavenging for discarded food, arrangements, negotiations, resisting, and mobilization practices through collecting can be better grasped. This approach also enables to go beyond an idiosyncratic analysis of each practice, to provide general theoretical insights about urban food gathering. Secondly, it argues that a critical geography perspective can be beneficial to frame this review, in order to develop a research agenda. As subsistence patterns are embedded within complex interrelated living conditions and capitals such as housing, economy, relations, regulations, values or knowledge, urban gathering is used as a proxy to analyze structural forms of power, exclusion, injustice, and inequality as well as alternative pathways. The research agenda thus mobilizes three bodies of work: urban informality studies, radical food studies, and urban political economy and ecology. Informal practices of collecting help understand not only survival strategy to alleviate hunger but also tactics to circumvent regulations that frame urban gathering as undesirable. A newly considered "right to collect" broadens the scope of food justice to provide opportunities to rethink relationships with capitalist food economies. Urban "patterns of gathering" question access to land and spaces, urban policies and managements, as well as urban transformations within spaces of advanced capitalism.

4 The following section surveys the multidisciplinary state of the art of urban collecting and identifies key themes and contradictions. The third section discusses the scope, issues, and research agenda for a critical geography of urban collecting.

\section{Analyzing urban food collecting: a multidisciplinary literature}

5 Urban food collecting is characterized by anthropology, ecology, geography, planning, and sociology on the basis of who collects and how, why people collect, what prevents people from collecting, and how urban collecting is controlled by local governments.

\section{Mutual practices within distinct groups, spaces, and temporalities}

6 People usually forage year round, particularly in spring, summer, and fall, which are active harvesting times owing to species availability, even if winter still offers gathering opportunities (Poe et al., 2013; Synk et al., 2017). People also scavenge all year long on a regular basis, typically one to four times per week, though sometimes even daily (Vinegar et al., 2016). Frequent outings both require and foster specific knowledge 
and relationships to places, goods, and taxa that are collected. Urban foragers thus often possess sophisticated local ecological knowledge which they pass on through family and friends, ecological instruction, field guides, and books (Poe et al., 2013). Dumpster divers possess knowledge about neighborhood garbage collection schedules, grocery stores discard routines, and are able to assess the best diving locations through "trash trailblazes" (Barnard, 2011).

7 Urban gatherer demographics are particularly diverse in age, gender, income, and ethnicity (McLain et al., 2014; Poe et al., 2013; Shackleton et al., 2017; Short Gianotti and Hurley, 2016; Synk et al., 2017; Vinegar et al., 2016). Both upper-middle-class individuals holding an alternative identity and food-insecure homeless people practice urban food collecting. Foragers include indigenous and non-indigenous life-long residents, as well as domestic and international immigrants (Poe et al., 2013). Similarly, urban scavengers and dumpster divers include a diversity of profiles such as high school teachers, mothers from low-income neighborhoods, and immigrant women (Barnard, 2011, 2016b; Ramirez, 2016). Within some low-income communities, half of the divers are homeless (Eikenberry and Smith, 2005). Despite fundamentally varied profiles, some gestures, values, and representations are shared by gatherers. Cooperation, gift giving, and social reciprocity are common among various types of gatherers, including homeless people as well as student communities (Eikenberry and Smith, 2005; Poe et al., 2013).

8 Yet this specific "shared material culture" (Guien and Ramirez, 2017, p. 49) is enacted in rather distinct manners, spaces and temporalities, suggesting latent practices of avoidance and of 'entre-soi'. For instance, in Montreal, food-insecure divers such as homeless people tend to be more isolated than food-secure divers such as university students who have stronger social connections (Vinegar et al., 2016). Caucasian prefer to dive in the daytime while non-Caucasians choose to dive at night to avoid being seen (ibid.). In the Pacific Northwest area, gatherers do no harvest the same species: salal, salmonberries, and nettles for indigenous communities; chestnuts, watercress, and plantains for Asian gatherers; and amaranth and aromatic healing herbs for Latino households (Poe et al., 2014). Newly arrived foragers recognize species from their homelands and appreciate them differently: the European mountain ash, considered a pest by urban ecologists in Seattle, is highly valued by Russian foragers for its berries.

\section{A marginal subsistence pattern}

9 Urban food collecting enables partial access to subsistence, most often as a supplement to other mainstream subsistence modes such as the conventional food system or other alternative pathways. Through self-provisioning and access to culturally salient foods, urban foraging can contribute to food security and sovereignty (McLain et al., 2014; Palliwoda et al., 2017; Poe et al., 2013). Forageables account for 1 to $47 \%$ of gatherers' diets in Baltimore, with a mean contribution of $7 \%$ and a greater reliance on foraged materials among low-income participants (Synk et al., 2017). Many food-insecure people prefer to dumpster dive because of a lack of access to food banks or soup kitchens, or rather than being dependent on governmental or organizational programs (Eikenberry and Smith, 2005). Homeless people face limited hours of operation, issues of transportation or access to kitchen facilities, or do not meet qualification requirements. Furthermore, people may object to the social stigma and feelings of 
dependence associated with charity. During times of misfortune, such as natural disasters or economic hardship, urban food collecting also acts as a coping strategy. Ninety-one species of wild plants and fungi were used by inhabitants trapped in the city during the siege of Sarajevo (Redzić, 2010). More recently, in Syracuse (New York), an immigrant group that had lost its urban garden foraged weeds from nearby vacant lots, thereby ensuring their families to meet critical short-term food needs (Shackleton et al., 2017).

10 Rather than to provide substantial food resources, urban collecting is actually most often used to transform the composition and quality of individuals' diets (McLain et al., 2014; Palliwoda et al., 2017). Gatherers documented 486 species in Seattle (Poe et al., 2013) and 170 taxa in Baltimore, most frequently fruits, nuts, berries and leaves (Synk et al., 2017). In Montreal, dumpster diving enabled participants to eat more exotic and expensive food, including produce, meat and dairy (Vinegar et al., 2016). Yet, in Minneapolis, the most common items reported from dumpster diving were doughnuts, pizza, and bread (Eikenberry and Smith, 2005), which suggests that scavengers collect according to availability, food habits, and location.

\section{Politics and pleasure}

11 Conversely as well as simultaneously to being a mode of subsistence, collecting can be performed as a political gesture or a pleasurable activity. Efforts to avoid capitalist modes of consumption and production have led some people to experiment strategies to alleviate needs or satisfy them differently. Many collectors describe themselves as "socially conscious" or "alternative" in reference to general lifestyle, identity, politics, or ideology (Vinegar, Parker, and McCourt, 2016). As commercial waste increase, freegans (Barnard, 2011, 2016b; Edwards and Mercer, 2012; Gross, 2009), ideologically motivated youth (Eikenberry and Smith, 2005) or "voluntary frugal ones" (Guien and Ramirez, 2017) engage in anti-consumerist practices. Dumpster diving is hence often associated with 'freeganism', a self-proclaimed anti-capitalist ideology adopted by individuals who wish to reduce waste and minimize their ecological footprint ${ }^{1}$. Freegans engage in practices such as dumpster diving, but also squatting, guerilla gardening, foraging, bicycling, hitchhiking, voluntary unemployment, and community activism (Barnard, 2011).

Beyond political motives, often used as a way of legitimating gathering, some refer to a "pleasure principle" shared by collectors, as gatherers express "excitement", "addiction" or "entertainment" (Guien and Ramirez, 2017), or conversely sadness and defiance if deterred (Poe et al., 2013). The joy of searching, classifying, and ordering plants could be interpreted as a legacy of the behavioral matrices of the "gathereranimal" that each of us was (Morizot, 2018, p. 106).

\section{To gather or not to gather}

Without actually detailing why it remains a marginal activity practiced by a minority, the recurrent barriers making urban food collecting hard to incorporate within ordinary urban lives can be addressed. Potential barriers to gleaning include lack of time due to contemporary urban rhythms (Synk et al., 2017), partition between labor and leisure, and powerful food consumption routines. Diving is particularly time- 
consuming and limited to specific hours due to the discard practices of the food trade. Some freegans reported giving up or limiting their practice because of lack of time for dumpster diving (Barnard, 2016b).

There may also be health risks associated with urban gathering that could drastically limit its potentialities. In addition to potential misidentification of species, people consuming materials foraged in urban settings may be exposed to chemical contaminants $^{2}$ (von Hoffen and Säumel, 2014; Synk et al., 2017; Weeks et al., 2006). Although very few cases of sickness due to urban foraging have been reported in the literature (Poe et al., 2013), sickness due to dumpster diving seems more frequent (Vinegar et al., 2016). Most gatherers actually adapt their practices to avoid health hazards. In the summer, people dive more frequently to avoid food safety issues (Vinegar et al., 2016). Some foragers stay away from sites with contaminated soils or exposed to traffic pollution, avoid plants from some families, and wash plant materials thoroughly (Poe et al., 2013; Synk et al., 2017). Awareness that buildings or vegetation act as barriers to reduce trace metal content in the edible biomass helps choose the particular site types for gathering.

15 Maybe more noteworthy, negative social norms or stigma associated with scavenging and more generally with waste prevent people from collecting discarded food (Eikenberry and Smith, 2005; Vinegar et al., 2016). The ability to overcome such stigma varies through acceptance of unconventionality within social circles, without systematic correlation with economic status. Therefore, access to specific social networks is key to acquire the necessary knowledge and overcome the various barriers that prevent people from collecting.

\section{Controlling urban collecting}

16 Land rights and urban planning regulations constitute fundamental barriers to gathering within urban spaces (Hurley et al., 2015; Shackleton et al., 2017; Svizzero, 2016). Prohibitions on harvesting plants on public land such as parks or conserved areas, as well as restrictions on diving in supermarket dumpsters and on scavenging on private property, have contributed to framing the practice of collecting as undesirable and unfit within contemporary cities. While there is a range of systems across different cities, most municipal regulations have either no explicit mention of foraging, or some form of restriction or prohibition (Shackleton et al., 2017). For example, Seattle's municipal code prohibits removing any plant part from city parks, namely to avoid the risk of "damaging" park resources (McLain et al., 2014). Violators of this law are subject to a fine of up to $\$ 5000$ or imprisonment of up to one year or both. Common fruit trees are prohibited in street planting strips, as fruits are likely to fall on the sidewalk, making the pavement dirty, and increasing the risk of pedestrian injuries.

However, the right to glean is still recognized in some legislation, such as in the French law. According to article R26-10 in the Penal Code $^{3}$ gleaning is authorized from sunrise to sunset after harvesting, including when it involves trespassing ${ }^{4}$. Similarly, uncollected waste and discarded artifacts are considered Res Derelictae or Res Nullius, abandoned objects that belong to whoever that collects them first. In France, this status applies to garbage, therefore legalizing dumpster diving or collecting abandoned objects providing that limiting conditions are respected, such as not dispersing waste on public roads or not trespassing. 
In parallel, some city governments are slowly beginning to support gleaning practices, often through partnerships with civil society groups. In France, the Parliament passed a law in 2016 against food waste, prohibiting supermarkets from discarding unsold items or making them unfit for consumption ${ }^{5}$. In Seattle, public tree fruit harvesting is emerging in city parks, signaling a shift in official policies toward harvesting in urban forests (McLain et al., 2012). Municipal authorities are also engaging in fighting food waste, for instance in Paris with the 2015-2020 Anti-Food Waste Plan and the 2016-2020 Paris Compost Plan. Nevertheless, the types of practices that are fostered reveal uneven treatments of varied forms of collecting. Municipalities often use the prohibition of scavenging as anti-poor legislation. Tree fruit harvesting or gathering food waste for charity organizations are supported by municipalities and advertised as 'innovative' or 'best' practices while dumpster diving or unauthorized gleaning are stigmatized and discouraged, especially when performed by and with marginalized groups such as the Roma or migrants.

\section{Towards a critical geography of urban food collecting: a research agenda}

19 To build up a research agenda I draw on critical geography literature to propose three renewed perspectives of urban food collecting. Using the notion of urban informality to analyze urban gathering makes it possible to see why it has long been framed by municipal authorities as an undesirable practice, and how actual practices interplay with and circumvent regulations. Considering a "right to collect food" broadens the scope of food justice, providing opportunities to capture ambivalent relations between capitalist food economies and gathering. Analyzing urban "patterns of gathering" (Shackleton et al., 2017) addresses the issue of access to land and spaces, urban policies and managements as well as urban transformations within spaces of advanced capitalism.

\section{Framing informal collecting practices as undesirable}

Collecting food partakes in urban informality through gathering in unauthorized premises, recuperating unclaimed goods, and selling them at times. A new light could be shed on gleaning practices if they were conceived as a series of arrangements in the margins of urban spaces and policies for urban low-income dwellers with difficult access to dominant spheres, as well as for intermediaries and elites. (Jacquot et al., 2016). How and where do unofficial practices of collecting edible resources take place in the city? In return, how are they considered and regulated by public authorities?

\section{Marginal spaces and economy of gathering}

21 Further studies on gathering food could contribute to a better understanding of spaces and the economy of urban informality. As a spatial categorization, informality is considered to be territorialized within "slum" settlements on the legal, political, economic, social and environmental margins of the city (McFarlane, 2012). In cities of the Global North, the spatiality of food collecting anchors on such margins, often taking places on the urban outskirts, in temporary or mobile settlements inhabited by 
migrants or nomadic populations, on vacant lots, within urban interstices, and in dumpsters. Urban gathering thus calls into question the role of spaces in supporting informal practices. Spaces and patterns of collecting change according to ecology, urbanization, regulations as well as cultures, tastes, seasonality or mobility capacities. As collecting practices are particularly mobile and labile, they design shifting, unbounded, and ever-changing territories. Conversely, collecting practices contribute to shaping, reconfiguring, or transforming urban spaces. Gathering and storing can enliven wasteland and scavenging can give an unseen value to a dumpster.

As an organizational form, informality is represented as unorganized and unregulated labor, although in practice such labor is often highly organized and disciplined (McFarlane, 2012). In order to circumvent conventional food systems, growing, selling, and acquiring food in cities occurred in multiple dissimulated ways, including growing edibles on wastelands, selling produce from allotment gardens, street-vending without a permit, picking up leftover produce from food markets, foraging berries in public parkland, and stealing from food retailers. Urban collecting thus contributes to household economies through exchanges in informal markets. Little is known about the informal economy of food gathering, yet some case studies show that it is highly organized and hierarchical within migration networks, and generates significant revenues (Hochedez, 2018). Other cases show less organized economic structures (Poe et al., 2013; Vinegar et al., 2016), suggesting a gradation in labor organization.

\section{From regulating to tolerating urban food collecting}

Foraging and scavenging are often prohibited by municipal regulations (McLain et al., 2014), suggesting that the divide between formal and informal often materializes as a governmental tool. Indeed, distinctions between formal and informal are deployed by states as organizational devices that allow or prohibit particular domains and forms of intervention (McFarlane, 2012). Despite being recognized in numerous countries, the right to glean is somewhat blurred ${ }^{6}$, as well as limited by private owners or public authorities through their right to enclose their land. In many countries, jumping the fences of a supermarket in order to rummage through its dumpsters can lead to court for violation of private property. Municipalities can also temporarily prohibit gleaning by adopting municipal decrees ${ }^{7}$, and it has become a common practice for supermarkets to pour toxic substances on their unsold items in order to discourage dumpster diving.

Regulations are nevertheless often unclear, subject to contentious cases, and infringed upon within gray zones. Rules on the books are prone to ambiguous interpretation or are rarely enforced, revealing tolerance towards these practices, and sometimes their legal recognition. For instance, if institutional rules often prohibit the collection of plants on public lands, some park managers recognize the benefits of environmental awareness and ecological knowledge that come from foraging. In some cases, authorities create convenience zones, institutionalizing informal practices (McLain et al., 2014).

In return, collectors deploy negotiation strategies, arrangements, resistance, and mobilizations to circumvent, fight, or interplay with regulations (Jacquot et al., 2016). In city parks, gathering still occurs under the radar and through tacit agreements with land managers (Poe et al., 2013; Short Gianotti and Hurley, 2016). In Paris, Tamil 
municipal garbage collectors allow some people to dumpster dive in exchange for their help with moving wheeled containers and compacting cardboard boxes (Ramirez, 2016). Yet these arrangements are intrinsically transient and subject to uneven abilities to mobilize resources and capitals. While Freegan communities often engage in strategies to "reverse the stigma" associated with food waste (Nguyen et al., 2014), other communities such as ragmen or the Roma less often encounter tolerance responses and continue to bear the negative stigma associated with scavenging. In vacant lots or urban forests, individuals leisurely foraging who encounter tolerant reactions are more likely to advocate for chasing away marginal communities using the same spaces, such as sex workers or homeless people.

\section{Informality as a negotiable value}

Because the relations between informal and formal are negotiable and changeable rather than fixed, informality is a "negotiable value" (Alsayyad and Roy, 2006; McFarlane, 2012), shifting, unset, and defined by unfixed boundaries. As practices, informality and formality exist as a kind of "meshwork" or "entanglement", mutually enabling or delimiting rather than antonymic (McFarlane, 2012). Regarding this assumption, the historical superposition of contradictory gleaning rights in the French Law indicates that there is a thin and shifting line between framing the practice of gleaning as gathering or considering it to be stealing. Indeed, collecting practices are often considered to take advantage of loopholes in ownership rights, assimilated to theft (see Thomas, 2010) or trespassing. This legally blurred situation highlights the historical and political character of the formal-informal divide. In turn, it means that informal gleaning is better understood as a production of the state itself rather than as the object of state regulations (Roy, 2005).

State regulations of collecting both reveal and fuel norms and stigmas associated with environmental conservation and management as well as ownership rights. To be better understood, informal food collecting practices need to be embedded within social systems and the values that structure them. Foraging in urban forests has been largely devalued within hygienist, recreational and conservationist paradigms, perpetuating the idea that cities no longer contribute to natural and subsistence resource livelihoods (Hurley and Halfacre, 2011). Interestingly, mainstream media and political discourses often oppose low-income people salvaging for economic motives and high-income people reusing for ethical, political or cultural motives, as if precarious households would always be acting under necessity and never by political choice (Guien and Ramirez, 2017).

\section{Gathering food (justice) in the city}

Literature about foraging and scavenging tackles issues such as food (in)security (see Synk et al., 2017) and food safety (von Hoffen and Säumel, 2014; Weeks et al., 2006), but rarely includes a food justice perspective. Similarly, the food justice literature has focused on urban agriculture and alternative food systems (Horst et al., 2017), rarely including gleaning among the pathways to alternative food resources, systems and powers. Food justice is considered a radical proposition intersecting class, race, culture, and gender to tackle inequities at all nodes of the food system (Holt-Giménez and Wang, 2011). This framework considers healthy food access and alternative pathways to 
the dominant corporate food regime (Holt-Giménez and Shattuck, 2011) within a broader context of social, racial, and environmental justice struggles spurred by structural inequities (Alkon and Agyeman, 2011). In contrast to a narrower focus on food security, the food justice and sovereignty scholarship examines political-economic dimensions of control over food resources. How does reclaiming a "right to collect food" challenge ways that food production, distribution, and consumption reproduce racial and economic inequalities? In what ways does urban collecting partake in exploring the possibilities for alternative relationships to capitalist food economies?

\section{Reclaiming a right to collect food}

29 Food justice recognizes the rights of local people to have control over their own culturally appropriate food systems, including access to resources and to the decisionmaking processes affecting related spaces. Only recently have some started to extend these rights to wild and place-based food systems and spaces (Poe et al., 2013). By providing food diversity through wild plants, urban gathering contributes to sustain the cultural identities and social relations of different urban populations, including indigenous peoples, settler populations, and recent immigrants. In Portland for instance, community organizations defend the right to "first foods" and to gather the roots and berries that tribal nations used to eat. Thus, the Native Gathering Gardens at Thomas Cully Park feature plants important for the Indigenous peoples of Portland, with a dedicated area for picking edible fruits, while gathering rights have been granted to Natives in parks on the Northwestern Pacific coast. In postcolonial settings, reclaiming a right to collect wild food thus relies on acknowledging historical, collective social trauma and undoing persistent race, gender, religious, citizenship, and class inequalities (Slocum et al., 2016).

The food justice scholarship also examines political-economic dimensions of control over food resources by scrutinizing the ways that food systems reproduce racial and economic inequalities. However, it is still unclear to what extent urban gathering will challenge structural racism and class inequalities. Race has seldomly been included in reflexions about urban food collecting, even if freeganism has been questioned as a "white privilege" movement (Barnard, 2016b). It thus echoes debates around whiteness, color-blindness and "entre-soi" in alternative food movements (Guthman, 2008). If urban scavenging activists recognize the work of social relations of power as the first step toward dismantling privilege, it is nonetheless unclear how it tackles it, since scavenging is not necessarily structured as a collective social movement. Rather than dismantling privilege, it could be argued that, while rediscovering the edibility of weeds or curbing waste production, foragers and scavengers may nonetheless reproduce power relations.

\section{Under the thumb of capitalist food economies}

31 The food justice framework also explores the possibilities for productive autonomy by local communities independent of capitalist food economies (Alkon and Agyeman, 2011). For gatherers identifying as "locavores", reducing food waste and "food miles", means eating from ultra-local sources such as harvesting mushrooms around the block or eating from the neighborhood bins. In this perspective, urban food collecting would allow individuals or groups to assert their rights to subsistence and economic activities 
involving non-capitalist exchanges (Poe et al., 2013). It would thus offer opportunities to counter the expansionist tendencies of capitalism and create a capacity to take advantage of crises through safety nets (Edwards and Mercer, 2012; Redzić, 2010).

Yet, rather than being totally independent from capitalism, urban gathering may better be explored as a "pericapitalistic practice", both inside and outside of capitalism (Tsing, 2017). Urban collecting resources are articulated with capitalism-dominated economies and forms of life, as gatherers most often keep shopping at the supermarket or resell collected matters to trade circuits further reincorporated into capital circulation. For instance, dumpster diving has been invalidated for its entanglement with the capitalist economy, as feeding on food waste is another way to absorb the surplus of the capitalist conventional food system. Accordingly, it could be argued that dumpster diving, and particularly freeganism, tend to celebrate waste rather than challenge its existence. Ironically, freeganism most often takes place in global cities relying on capitalist processes: even though Freegans in New York City are opposed to paying rent and wage earning, nearly all of them do since they feel compelled to accept an "unpleasant reality" (Barnard, 2016b).

\section{Deciphering urban transformations through "patterns of gathering"}

Urban gathering is jeopardized by urban sprawl, privatization, and loss of urban commonage. What can the exploration of routes and habits of urban collecting, i.e. "patterns of gathering" (Shackleton et al., 2017), reveal about urban transformations? How can those patterns and their reconfigurations help to decrypt larger urban dynamics, embedded within power alliances, management regimes, and land ownership?

\section{Development, densification, gentrification, and abandonment}

The constant reconfiguration of urban landscapes through processes such as development, densification, gentrification, and abandonment is critical to understanding how different ranges of people have access to and can enact urban gathering (Hurley et al., 2015; Shackleton et al., 2017). These transformations reconfigure the location, size, distribution, nature, management of, and access to the ecologies and green spaces that support gathering. This often results in loss of access for foragers, as well as a potential change in species diversity, even if remnant patches still offer opportunities.

Densification processes withdraw, fragment, and deteriorate available places for foraging. Urban sprawl takes on a patchy form, resulting from the combination of zoning, land conservation and clustering policies. The ecological degradation of habitats due to urban expansion is often associated with increased sewage in lakes, the conversion of wetlands, forests, and fields to housing, and the destruction of street trees for road expansion. Hence, foragers seeking a diverse and substantial quantity of resources may need to cross a broader landscape to escape densification (Hurley et al., 2015; Synk et al., 2017). Similarly, urban development transforms green spaces within city boundaries, thus jeopardizing the access of different communities to natural resources and their economic survival. Specifically in neighborhoods receiving substantial capital investment and an influx of more affluent residents, gentrification is 
likely to create conflicts, as the ideas of formerly and newly settled residents differ about how best to interact with natural resources and landscapes.

Conversely, through the production of wastelands, vacant lots, and unbuilt areas, land abandonment is considered to provide gathering opportunities within urban areas. In almost all northern metropolises, and specifically in shrinking cities, land markets and policies create land vacancy, providing transient opportunities for species to spur in abandoned areas and for gatherers to access edible species (Hurley et al., 2015). For instance, in Detroit, where massive land abandonment occurred following deindustrialization and capital disinvestment, practices of foraging for wild plants, gleaning from fruit trees, hunting raccoons, as well as scrapping metals, have been documented (Millington, 2013; Paddeu, 2016). Urban gathering could thus be investigated as a set of marginal yet adaptive practices in a context of austerity.

\section{Privatization, loss of the commons, and land rights}

37 A central issue with respect to foraging is access to land and to resource habitats. Thus, changes in ownership patterns, land tenure, and land management strategies challenge access to key plant materials and to the continuation of urban gathering (Shackleton et al., 2017). While foraging was associated with common property regimes in the premodern world (Svizzero, 2016), common property regimes are scarce in the capitalist world and threatened by privatization. Exclusive property rights have been generalized, especially in the Global North. This shift translates into fences, security guards, and regular patrols, as well as into changes in landscaping design (Hurley et al., 2015). The reconfiguration of spaces forces gatherers to be more adaptive, innovative, and knowledgeable about alternative sites, species, and uses. Nevertheless, gatherers are affected differently by urban and land transformations. Commons can be crucial for recent migrants in peri-urban areas, depending more on the harvest of wild natural resources, while longtime residents in established parts of cities can invest more in urban agriculture and private spaces where they have established networks and rights of access (Shackleton et al., 2017).

Practices of gathering thus trigger a conversation about land rights and land justice for gleaners. According to Holt-Giménez (2017), changing the food system without changing the systems of land access, land tenure, and land use is not only unlikely, but impossible, as changing land politics is to change property politics. Rethinking access to land in the city thus demands thinking beyond basic issues of availability and spatial distribution of potential foraging sites, in order to engage in deeper-reaching political debates over race, space, and justice that shape property relations, and to confront the longstanding inequities and systems of oppression that imposed these relations (Safransky, 2017).

\section{Grasping urban political ecologies of green spaces}

How does the distribution of urban nature potentially affect gatherers, what spaces become available to them, and how do gatherers navigate power relationships with land managers and owners (see Byrne and Wolch, 2009; Heynen, 2003)? Political ecology provides a framework for understanding how the production of green space impacts gatherers through changing material and institutional practices. In addition, it enables one to investigate changes of perceptions about "appropriate" uses of spaces and their 
plants, including management strategies commonly prioritizing esthetics and recreation (Short Gianotti and Hurley, 2016; McLain et al., 2014). Many urban conservation programs typically prohibit direct material interactions between humans, flora, and fauna (Hurley and Halfacre, 2011). At the same time, there is a renewed interest in the role of food production within some park spaces, including cases of creating orchards and agroecological landscapes within city parks, and planting food crops within street easements (Blanc and Paddeu, 2018; McLain et al., 2012). However, some of these programs appear to maintain a two-tier system, in which only a limited number of purposefully planted species and deliberately maintained spaces are recognized, while many other species, areas, and practices are not.

Biological diversity and gatherers' access to valued species are shaped by ecological patterns, migration of humans and other species, and environmental management. Following patterns of gathering could inform about ecological characteristics as well as their reconfigurations though migrations, assemblages, and hybridations. Urban areas can provide opportunities in correlation with the presence of "synurbic species", i.e. species that are associated with urban areas to a greater extent than other ecosystems (Francis and Chadwick, 2012). Urban foraging contributes to the recognition that invasive and non-native species may provide ecological and social benefits. Biodiversity loss due to potentially damaging harvesting practices has been raised as a concern (Shackleton et al., 2017), yet there is little evidence. Conversely, most gatherers tend plants and harvest in ways to ensure their vigor and abundance, as well as to preserve resources for other users (Poe et al., 2013). Researchers in Japan have even documented the positive role of regularly harvesting fuelwood and edible roots in creating habitat for endangered wildlife (Kobori and Primack, 2003), suggesting possible diplomatic relationships with living beings (Morizot, 2016).

41 Food waste and wild plants are increasingly understood in a more-than-human relational context. Understanding urban foraging through "relational ecologies of belonging" (Poe et al., 2013) opens up imaginative, albeit radical, possibilities for living "within the ruins of capitalism" (Tsing, 2017). Urban gathering may occur within forested areas unaffected by urban development as well as in typical suburban landscapes, such as ornamental plantings near planned unit developments and commercial shopping centers, parking lot medians, or between highways. Surprising alliances can arise within what Tsing (ibid.) calls "latent commons", open to nonhumans and mutual entanglements, unequal and selective, interstitial and resisting institutionalization, troubled and uncontrolled. For instance, faced with shifts in growing patterns in South Carolina, some low-income gatherers for basket-weaving have started to seek cooperation from upper-class suburban newcomers living in gated communities in order to facilitate their access to sweetgrass (Hurley et al., 2015). Hence, these gatherers have created new relationships with the urban landscapes of contemporary northern cities as well as new forms of "latent commons", in expensive suburban landscaping, through unexpected and ambivalent alliances, with precarious access to resources and within uneven conditions.

\section{Conclusions}

This paper aimed at defining the scope and an initial agenda for a critical geography of urban food collecting. It started with an overview of a multidisciplinary literature 
regarding both foraging and scavenging in order to develop a theoretical understanding of urban food collecting. Drawing on three bodies of critical geography literature, namely urban informality studies, radical food studies, and urban political economy and ecology, this paper explores how investigating urban food collecting enhances the analysis of structural forms of power, exclusion, injustice, and inequality as well as alternative pathways in urban spaces of advanced capitalism.

Following the review of literature, urban food collecting seems to foster shared practices and culture between different social groups although performed in distinct spaces and temporalities, suggesting latent practices of avoidance and "entre-soi". Several barriers such as powerful food consumption routines, lack of time, health security, and stigma make it extremely difficult to incorporate food collecting within urban lives and unevenly accessible to different communities. If some city governments have timorously started to support gathering practices, closures of land and regulations that prevent harvesting do contribute to framing food collecting as an undesirable practice within contemporary cities. Furthermore, urban collecting conveys diverging representations, as scavenging for food continues to bear the stigma associated with waste while foraging has recently gained momentum, associated with revitalized relationships with fauna and flora. As urban food collecting practices are rapidly shifting, importance should be granted to possible issues of conflicting sharing of spaces and resources among individuals with uneven capitals, especially as urban foraging appeals increasingly to upper and middle class urbanites.

On the grounds of these analyses, the combination of different bodies of critical geography literature helps to build a theoretical understanding of urban food collecting. Firstly, urban informal studies show that even if prohibitive regulations frame urban food collecting as mostly unwanted, tolerance behaviors indicate unequal treatments of communities facing double standards. Considering that urban informality is a negotiable value produced by the State (Roy, 2005), it sheds a new light on the ways in which state regulations of collecting both reveal and fuel norms and stigmas associated with gathering regarding, race, class, environmental conservation and management, and ownership rights. Secondly, following radical food studies, in postcolonial settings, acknowledging historical, collective social trauma and undoing persistent race, gender, religious, citizenship, and class inequalities are fundamental to reclaiming a right to collect wild food. Yet, some doubts remain about the ability of urban gathering to challenge structural racism and class inequalities in particular, as foragers and scavengers reproduce power relations. If urban gathering aims at more productive autonomy, its close articulation with capitalist food systems and economies makes it more likely to be explored as a "pericapitalistic practice", both inside and outside of capitalism (Tsing, 2017). Thirdly, the examination of urban "patterns of gathering" (Shackleton et al., 2017) allows to investigate the diminished access to collecting through privatization and loss of the commons as well as through neighborhood changes of socio-demographics, values and landscapes. As different gatherers are not affected the same way by these transformations because of unequal social and land capitals, it raises issues of "land justice" relying on longstanding inequities and systems of oppression. Uneven systems of power pave the way to unexpected and fundamentally ambivalent alliances through "latent commons" within the "ruins of capitalism" (Tsing, 2017). 
estigating urban collecting opens further multidisciplinary research avenues on the genealogy of rights to glean, commoning processes through urban food collecting, and "diplomatic relationships with living beings" (Morizot, 2016). Most importantly it paves the way for a relational approach to urban food collecting within both the urban Global South and North, as foraging is practiced in Bangalore or Delhi (Gopal and Nagendra, 2014); in Uganda, Senegal (NDao and MBaye, 2017) and South Africa; and as scavenging is well documented in Calcutta or Faisalabad (Batool and Anjum, 2016). Ironically, "dumpster diving" has been considered a voluntary alternative practice within cities of the Global North whereas "scavenging" has been more often associated with people in need within cities of the Global South. A more thorough investigation of Southern case studies, embedded within domination and postcolonial power relationships, opens new horizons to rethink urban food collecting.

\section{BIBLIOGRAPHY}

Alkon A., Agyeman J. (eds), 2011. Cultivating Food Justice: Race, Class, and Sustainability. Cambridge, MA, MIT Press, $408 \mathrm{p}$.

Alsayyad N., Roy A., 2006. Medieval Modernity: On Citizenship and Urbanism in a Global Era. Space and Polity, vol. 10, $\mathrm{n}^{\circ}$ 1, p. 1-20.

Barnard A., 2011. 'Waving the Banana' at Capitalism: Political Theater and Social Movement Strategy among New York’s ‘Freegan’ Dumpster Divers. Ethnography, vol. 12, nº 4, p 419-444.

Barnard A., 2016. Making the City 'Second Nature': Freegan 'Dumpster Divers' and the Materiality of Morality. American Journal of Sociology, vol. 121, n 4, p. 1017-1050.

Batool Z., Anjum F., 2016. A sociological study of trash picker children in Faisalabad City, Punjab, Pakistan. Pakistan Journal Life of Social Sciences, vol. 14, $\mathrm{n}^{\circ} 1, \mathrm{p} .33-37$.

Blanc N., Paddeu F., 2018. L'environnementalisme ordinaire. Transformer l'espace public métropolitain à bas bruit ? EspaceTemps.net [En ligne]. https://www.espacestemps.net/articles/ lenvironnementalisme-ordinaire-transformer-lespace-public-metropolitain-a-bas-bruit/

Byrne J., Wolch J., 2009. Nature, Race, and Parks: Past Research and Future Directions for Geographic Research. Progress in Human Geography, vol. 33, n 6, p. 743-765.

Edwards F., Mercer D., 2012. Food Waste in Australia: The Freegan Response. The Sociological Review, vol. 60, n 2, p. 174-191.

Eikenberry N., Smith C., 2005. Attitudes, Beliefs, and Prevalence of Dumpster Diving as a Means to Obtain Food by Midwestern, Low-Income, Urban Dwellers. Agriculture and Human Values, vol. 22, $\mathrm{n}^{\circ} 2$, p. 187-202.

Francis R., Chadwick M., 2012. What Makes a Species Synurbic? Applied Geography, vol. 32, n² p. 514-521.

Gopal D., Nagendra H., 2014. Vegetation in Bangalore's Slums: Boosting Livelihoods, Well-Being and Social Capital. Sustainability, vol. 6, n 5, p. 2459-2473.

EchoGéo, 47 | 2019 
Gross J., 2009. Capitalism and Its Discontents: Back-to-the-Lander and Freegan Foodways in Rural Oregon. Food and Foodways, vol. 17, n², p. 57-79.

Guien J., Ramirez V., 2017. Travailler à consommer, Labouring consumption. Terrains \& travaux, $n^{\circ} 31$, p. 45-62.

Guthman J., 2008. Bringing Good Food to Others: Investigating the Subjects of Alternative Food Practice. Cultural Geographies, vol. 15, n 4, p. 431-447.

Heynen N., 2003. The Scalar Production of Injustice within the Urban Forest. Antipode, vol. 35, $\mathrm{n}^{\circ}$ 5, p. $980-998$.

Hochedez C., 2018. Migrer et cultiver la ville : l'agriculture communautaire à Malmö (Suède). Urbanités [En ligne], n 10. http://www.revue-urbanites.fr/10-hochedez-malmo/

Hoffen L-P., Säumel I., 2014. Orchards for Edible Cities: Cadmium and Lead Content in Nuts, Berries, Pome and Stone Fruits Harvested within the Inner City Neighbourhoods in Berlin, Germany. Ecotoxicology and Environmental Safety, $n^{\circ} 101$, p. 233-239.

Holt-Giménez E., 2017. A Foodie's Guide to Capitalism: Understanding the Political Economy of What We Eat. Oakland, CA, Monthly Review Press, 256 p.

Holt-Giménez E., Shattuck A., 2011. Food Crises, Food Regimes and Food Movements: Rumblings of Reform or Tides of Transformation? The Journal of Peasant Studies, vol. 38, n 1, p. 109-144.

Holt-Giménez E., Wang Y., 2011. Reform or Transformation? The Pivotal Role of Food Justice in the U.S. Food Movement. Race/Ethnicity: Multidisciplinary Global Contexts, vol. 5, nº 1, p. 83-102.

Horst M., McClintock N., Hoey L., 2017. The Intersection of Planning, Urban Agriculture, and Food Justice: A Review of the Literature. Journal of the American Planning Association, vol. 83, $\mathrm{n}^{\circ} 3$, p. 277-295.

Hurley P., Emery M., McLain R., Poe M., Grabbatin B., Goetcheus C., 2015. Whose Urban Forest? The Political Ecology of Foraging Urban Nontimber Forest Products. In Issenhour C., McDonogh G. Checker M., Sustainability in the Global City, Myth and Practice. New York, Cambridge University Press, p. 187-212.

Hurley P., Halfacre A., 2011. “odging Alligators, Rattlesnakes, and Backyard Docks: A Political Ecology of Sweetgrass Basket-Making and Conservation in the South Carolina Lowcountry, USA. GeoJournal, vol. 76, 4, p. 383-399.

Jacquot S., Sierra A., Tadié J., 2016. "Informalité politique, pouvoirs et envers des espaces urbains." L'Espace Politique. Revue en ligne de géographie politique et de géopolitique, n² 29, http:// journals.openedition.org/espacepolitique/3805

Kangas K., Markkanen P., 2001. Factors Affecting Participation in Wild Berry Picking by Rural and Urban Dwellers. Silva Fennica, vol. 35, n 4, p. 487-495.

Kobori H., Primack R., 2003. Participatory Conservation Approaches for Satoyama, the Traditional Forest and Agricultural Landscape of Japan. Ambio, vol. 32, n 4, p. 307-311.

McFarlane C., 2012. Rethinking Informality: Politics, Crisis, and the City. Planning Theory \& Practice, vol. 13, n 1, p. 89-108.

McLain R., Hurley P., Emery M., Poe M., 2014. Gathering 'Wild' Food in the City: Rethinking the Role of Foraging in Urban Ecosystem Planning and Management. Local Environment, vol. 19, $\mathrm{n}^{\circ} 2$, p. $220-240$. 
McLain R., Buttolph L., Poe M., MacFarland K., et al. 2012. Gathering in the City: An Annotated Bibliography and Review of the Literature about Human-Plant Interactions in Urban Ecosystems [En ligne]. http://digitalcommons.ursinus.edu/environment_fac/10/

Millington N., 2013. Post-Industrial Imaginaries: Nature, Representation and Ruin in Detroit, Michigan. International Journal of Urban and Regional Research, vol. 37, nº 1, p. 279-296.

Morizot B., 2016. Les Diplomates, Cohabiter avec les loups sur une nouvelle carte du vivant. Paris, Wildproject, $320 \mathrm{p}$.

Morizot B., 2018. Sur la piste animale. Actes Sud. Paris, Mondes Sauvages, 200 p.

NDao M., MBaye Diouf E., 2017. L'arboriculture fruitière, une menace pour la biodiversité, exemple de la commune de Niaguis (Zinguichor, Sénégal), Liens, vol. 23, nº 2, p. 176-189.

Nguyen H., Chen S., Mukherjee S., 2014. Reverse Stigma in the Freegan Community. Journal of Business Research, vol. 67, n 9, p. 1877-1884.

Oakes P., 2000. Why Freegan? An Attack on Consumption - In Defense of Donuts [En ligne]. https:// freegan.info/what-is-a-freegan/freegan-philosophy/why-freegan-an-attack-on-consumption-indefense-of-donuts/

Paddeu F., 2016. Les ruines de Détroit, fléaux ou opportunités de la décroissance urbaine ? Vers une éthique politique de la ruine. Frontières [En ligne], vol. 28, n 1. https://id.erudit.org/ iderudit/1038863ar

Palliwoda J., Kowarik I., Lippe M., 2017. Human-Biodiversity Interactions in Urban Parks: The Species Level Matters. Landscape and Urban Planning, $\mathrm{n}^{\circ}$ 157, p. 394-406.

Plieninger T., Bieling C., Fagerholm N., Byg A., et al., 2015. The Role of Cultural Ecosystem Services in Landscape Management and Planning. Current Opinion in Environmental Sustainability, $\mathrm{n}^{\circ} 14$, p. 28-33.

Poe M., Le Compte J., McLain R., Hurley P., 2014. Urban Foraging and the Relational Ecologies of Belonging. Social \& Cultural Geography, vol. 15, n 8, p. 901-919.

Poe M., McClain R., Emery M., Hurley P., 2013. Urban Forest Justice and the Rights to Wild Foods, Medicines, and Materials in the City. Human Ecology, vol. 41, n 3, p. 409-422.

Ramirez V., 2016. De l'art de chambarder la société de consommation. Portrait d'un récupérateur. Techniques \& Culture, $\mathrm{n}^{\circ}$ 65-66, p. 290-293.

Redzić S., 2010. Use of Wild and Semi-Wild Edible Plants in Nutrition and Survival of People in 1430 Days of Siege of Sarajevo during the War in Bosnia and Herzegovina (1992-1995). Collegium Antropologicum, vol. 34, $\mathrm{n}^{\circ}$ 2, p. 551-570.

Roy A., 2005. Urban Informality: Toward an Epistemology of Planning. Journal of the American Planning Association, vol. 71, n², p. 147-158.

Safransky S., 2017. Rethinking Land Struggle in the Postindustrial City. Antipode, vol. 49, $\mathrm{n}^{\circ} 4$, p. $1079-1100$.

Shackleton C., Hurley P., Dahlberg A., Emery M., Nagendra H., 2017. Urban Foraging: A Ubiquitous Human Practice Overlooked by Urban Planners, Policy, and Research. Sustainability, vol. $9, \mathrm{n}^{\circ} 10$, p. 1884. https://doi.org/10.3390/su9101884

Short Gianotti A., Hurley P., 2016. Gathering Plants and Fungi along the Urban-Rural Gradient: Uncovering Differences in the Attitudes and Practices among Urban, Suburban, and Rural Landowners. Land Use Policy, n 57, p. 555-563. 
Slocum R., Cadieux K., Blumberg R., 2016. Solidarité, espace et « race » : vers des géographies de la justice alimentaire." Justice Spatiale Spatial Justice [En ligne], nº 9. https://www.jssj.org/article/ solidarite-espace-et-race-vers-des-geographies-de-la-justice-alimentaire/

Svizzero S., 2016. Foraging Wild Resources: Evolving Goals of an Ubiquitous Human Behavior. Anthropology, vol. 4, $\mathrm{n}^{\circ}$ 1, p. 1-9.

Synk C., Kim B., Davis C., Harding J., et al., 2017. Gathering Baltimore's Bounty: Characterizing Behaviors, Motivations, and Barriers of Foragers in an Urban Ecosystem. Urban Forestry \& Urban Greening, $\mathrm{n}^{\circ} 28$, p. 97-102.

Terada T., Yokohari M., Bolthouse J., Tanaka N., 2010. Refueling Satoyama Woodland Restoration in Japan: Enhancing Restoration Practice and Experiences through Woodfuel Utilization. Nature and Culture, vol. $5, n^{\circ} 3$, p. 251-276.

Thomas S., 2010. Do Freegans Commit Theft? Legal Studies, vol. 30, n 1, p. 98-125.

Tsing A., 2017. The Mushroom at the End of the World. Princeton, NJ, Princeton University Press, $352 \mathrm{p}$.

Vinegar R., Parker P., McCourt G., 2016. More than a Response to Food Insecurity: Demographics and Social Networks of Urban Dumpster Divers. Local Environment, vol. 21, n 2, p. 241-253.

Weeks C., Croasdale M., Osborne M., Hewitt L., et al., 2006. Multi-Element Survey of Wild Edible Fungi and Blackberries in the UK. Food Additives \& Contaminants, vol. 23, n 2, p. 140-147.

\section{NOTES}

1. Freeganism ambivalence and contradictions will be considered further.

2. However, in Berlin, supermarket samples of some fruits exhibited higher levels of cadmium and lead than inner city samples of foraged materials (von Hoffen and Säumel, 2014).

3. Article R26 of the Penal Code, consulted on July 12 2018. https://www.legifrance.gouv.fr/ affichCodeArticle.do?

idArticle=LEGIARTI000006490552\&cidTexte=LEGITEXT000006071029\&dateTexte $=19940228 /$

4. Blog post "Retour et métamorphoses du droit de glanage, racine historique des Communs ", posted on February 6 2016, consulted on July 12 2018. https://scinfolex.com/2016/02/06/retouret-metamorphoses-du-droit-de-glanage-racine-historique-des-communs/

5. Article « La loi sur la lutte contre le gaspillage alimentaire adoptée au Parlement », published on February 3 2016, consulted on July 12 2018. http://www.lemonde.fr/planete/article/ 2016/02/03/la-loi-sur-la-lutte-contre-legaspillage-alimentaire-adoptee-au-

parlement_4858807_3244.html?

utm_medium=Social\&utm_source=Twitter\&utm_campaign=Echobox\&utm_term=Autofeed\#link_time=1454520402

6. Article «Pauvreté : le retour du glanage», published on October 17 2011, consulted on July 12 2018: https://blogs.mediapart.fr/gillessainati/blog/161011/pauvrete-le-retour-duglanage

7. In Nogent-sur-Marne, a suburban city located in the Greater Paris area, an "anti-poor" decree was used to prohibit scavenging in 2011, but the League for Human Rights obtained its suspension, pleading the right of people in dire need to freely scavenge discarded goods, especially during winter time, published on November 22 2011, consulted on July 122018. https://94.citoyens.com/2011/le-tribunal-suspend-larrete-anti-chiffonage-a-nogent-sur-marne, 22-11-2011.html 


\section{ABSTRACTS}

The aim of this paper is to define the scope and an initial agenda for a critical geography of urban food collecting. It provides an overview of a multidisciplinary literature regarding patterns of foraging and scavenging to develop a theoretical comprehension of urban collecting in contemporary northern cities. Drawing on three bodies of critical geography literature, namely urban informality studies, radical food studies, and urban political economy and ecology, it advocates that investigating urban food collecting provides a tool to analyze structural forms of power, exclusion, injustice and inequality as well as alternative pathways in spaces of advanced capitalism.

Cet article propose de définir la portée et le programme liminaire d'une géographie critique du glanage alimentaire urbain. Pour cela, nous effectuons une revue de littérature pluridisciplinaire portant sur le glanage d'espèces comestibles sauvages ou cultivées ainsi que de déchets alimentaires, dans le but de développer une analyse théorique du glanage alimentaire dans les villes contemporaines des Nords. Faisant appel à trois corpus de la géographique critique, à savoir les études sur l'informalité urbaine, les études radicales sur l'alimentation, l'économie et l'écologie politiques urbaines, nous soutenons l'idée que l'étude du glanage alimentaire urbain permet d'analyser des formes structurelles de pouvoir, d'exclusion, d'injustice et d'inégalité ainsi que les alternatives dans les espaces du capitalisme.

\section{INDEX}

Mots-clés: cueillette, géographie critique, glanage alimentaire, récupération, système alimentaire alternatif

Keywords: alternative food system, critical geography, foraging, urban food collecting, scavenging

Subjects: Sur le Champ - Sur le Terrain

\section{AUTHOR}

\section{FLAMINIA PADDEU}

Flaminia Paddeu, flaminia.paddeu@univ-paris13.fr, est Maître de Conférences en géographie, Université de Paris 13-Villetaneuse, laboratoire PLEIADE - EA 7338. Elle a récemment publié - Blanc N., Paddeu F., 2018. L'environnementalisme ordinaire. Transformer l'espace public métropolitain à bas bruit ?. EspacesTemps.net [En ligne], Travaux. https://www.espacestemps.net/ articles/lenvironnementalisme-ordinaire-transformer-lespace-public-metropolitain-a-bas-bruit/ - Paddeu F., 2017. Sortir du mythe de la panacée. Les ambiguïtés de l'agriculture urbaine à Détroit. Métropolitiques [En ligne]. http://www.metropolitiques.eu/Sortir-du-mythe-de-lapanacee-Les.html

- Paddeu F., 2017. Agir à l'heure de l'anthropocène. Les quatre familles de l'environnementalisme urbain. L'Information géographique, vol. 81, n 3, p. 32-53. 